\title{
Effect of copepods on estuarine microbial plankton in short-term microcosms
}

\author{
J. Sipura ${ }^{1, *}$, E. Lores ${ }^{2}$, R. A. Snyder ${ }^{3}$ \\ ${ }^{1}$ Department of Biology, Section of Ecology, University of Turku, Turku 20014, Finland \\ ${ }^{2}$ US Environmental Protection Agency, Gulf Ecology Division, 1 Sabine Island Drive, Gulf Breeze, Florida 32561, USA \\ ${ }^{3}$ Center for Environmental Diagnostics and Bioremediation, Biology Department, University of West Florida, \\ 11000 University Parkway, Pensacola, Florida 32514, USA
}

\begin{abstract}
We examined the effects of copepod feeding on estuarine microbial plankton, including bacteria, cyanobacteria, heterotrophic and autotrophic nanoflagellates, microzooplankton and larger phytoplankton cells, to elucidate any short-term control or release phenomena. As an example of such potential effects, it was hypothesized that through omnivory Acartia tonsa would reduce both competitors (large phytoplankton) and predators (microzooplankton) of small autotrophic flagellates, allowing the latter to proliferate. Copepod addition and removal treatments were conducted in 241 containers in triplicate. As expected, the copepods significantly decreased both microzooplankton and large phytoplankton populations, and blooms of ciliates and diatoms (the dominant phytoplankton group) were apparent in the copepod removal treatment. Effects were qualitative (species composition changes) as well as quantitative. However, beyond this immediate impact, community level cascades in the microbial food web were not found, likely due to consumer recycling of resources and trophic level heterogeneity. Bacterioplankton responded positively to the addition of copepods, but negatively to the bloom of diatoms in the copepod removal treatment. These results suggest that the effects of copepods on the structure and function of estuarine microbial plankton communities may be more complex than simple linear effects would predict.
\end{abstract}

KEY WORDS: Acartia tonsa · Microbial plankton · Grazing · Recycling · Trophic cascade - Resale or republication not permitted without written consent of the publisher

\section{INTRODUCTION}

The coastal waters of all densely populated coastal areas receive substantial anthropogenic nutrient loading (Nixon 1995). Increased nuisance algal blooms are thought to be the most harmful symptom of eutrophication in these waters (e.g. Hallegraeff 1993), and research has largely focused on extrinsic resource regulation of these systems (Verity \& Smetacek 1996). Even though a clear positive relationship between nutrient enrichment and overall autotrophic production has been shown (Pearl \& Whittall 1999), this approach has not been successful in predicting the timing, magnitude or temporal dynamics of plankton communities (Verity \& Smetacek 1996). The residual variation in plankton dynamics is likely due to intrinsic biological and physical-chemical factors and their interactions in coastal aquatic systems.
Although resources undeniably set the limits for production within a system, consumers have the potential to regulate how and where that production occurs (Hairston et al. 1960: green world hypothesis). Consumer effects can extend to indirect, complex interactions within communities. Strong interactions (sensu Paine 1980) within food webs can even lead to trophic cascades, where a top-down effect imposed by predators on their prey biomass cascades down to lower trophic levels and plays an important role in determining the overall structure of a community (Paine 1980, Carpenter et al. 1985). Several authors have argued that in speciose systems with high levels of omnivory and heterogeneity, community level trophic cascades are rare (Strong 1992, Polis 1999, see also Polis et al. 2000).

Conceptually, a near uniform impact on a size class by an omnivore such as Acartia tonsa has the potential 
to induce a cascade effect on smaller size-classes. $A$. tonsa feeding on microzooplankton and larger phytoplankton cells would reduce both predators and competitors of small autotrophic flagellates, which in turn should proliferate. Removal of microzooplankton also reduces predation on heterotrophic flagellates, which potentially increases nanoflagellate bacterivory. Existing data for trophic cascade effects in planktonic microbial food webs are variable (e.g. Dolan \& Gallegos 1991, Calbert et al. 2001) and, aside from the fishDaphnia-phytoplankton cascades, their importance in plankton dynamics still seems to be an open question.

The direct effects of predators on prey populations are confounded by positive feedbacks, where predators affect lower trophic levels through resource regeneration (e.g. Snyder \& Hoch 1996). This phenomenon is especially pronounced in microbial food webs where scales of organismal dispersion, size and growth rates are tightly coupled. In addition to this direct consumer recycling, phytoplankton exudates are thought to be a major source of substrates for bacterial growth (Bird \& Kalff 1984, Cole et al. 1988) although zooplankton feeding activities may also be important in this regard (Roman et al. 1988, Jumars et al. 1989, Vadstein et al. 1989).

In this study, we examined the qualitative and quantitative effects of zooplankton feeding on an estuarine microbial food web with Acartia tonsa as the dominant top predator. Some copepods, like $A$. tonsa in this system, are omnivorous, feeding on both microzooplankton and phytoplankton. Gismervik et al. (1996) call for special attention to species with such behavioral plasticity as potential key species in structuring marine pelagic food webs, acting similarly to Daphnia in fresh waters.

\section{MATERIALS AND METHODS}

The water for the experiment was obtained from the mouth of Bayou Texar, Pensacola Bay, Northwest Florida $\left(30^{\circ} 25^{\prime} \mathrm{N}, 87^{\circ} 11^{\prime} \mathrm{W}\right)$ during a high tide (salinity $19 \%$ ). The water was filtered through a zooplankton net (202 $\mu \mathrm{m}$ mesh size). Six 241 semitransparent polyethylene containers ( $\mathrm{HCl}$ washed) were filled with the filtered water and transferred to the laboratory. The containers were randomly assigned to copepod removal and addition treatments. Copepods (mainly Acartia tonsa) for the addition treatment were obtained from the adjacent Pensacola Bay bridge (salinity $21 \%$ ) with a zooplankton net $(202 \mu \mathrm{m}$ mesh size). The copepods were poured into a 41 plastic container containing filtered sea water and transferred immediately to the laboratory where the water with the gathered copepods was allowed to stand so suspended material would settle. After approximately
30 min, live free-swimming copepods were removed and divided between the 3 copepod addition treatment containers. Samples were then taken for determination of starting conditions (see below).

The experiment was conducted in a temperatureand light-controlled floor-shaker incubator. The temperature was kept at $28^{\circ} \mathrm{C}$, which was within the temperature range of the source habitat. A light-dark cycle $(12: 12 \mathrm{~h}, 3220 \mathrm{~lx})$ was established. A small volume of air ( 0.5 to 1 l) was maintained in each container to facilitate mixing. The speed of rotation was adjusted so that the movement of bulk water dominated over turbulent mixing.

The containers were sampled immediately after setup and approximately every $12 \mathrm{~h}$ for bacteria, picocyanobacteria, flagellates, ciliates, copepod nauplii and bacterial activity. Phytoplankton and bacterial community structures were analyzed 2 times and phytoplankton pigments 3 times during the experiment. The phytoplankton sample taken at the beginning of the experiment was a composite of subsamples from each container. Copepods (adults and copepodite stages combined) and copepod fecal pellets were counted approximately every $24 \mathrm{~h}$.

Bacteria, picocyanobacteria and flagellates were preserved with formaldehyde ( $2 \%$ final conc.). The samples were dyed with DAPI (after Porter \& Feig 1980), filtered on black 0.2 (bacteria and picocyanobacteria) or $0.8 \mu \mathrm{m}$ (flagellates) Poretics filters, and processed immediately (picocyanobacteria) or frozen until counted. The samples were counted with a Nikon Optiphot-2 epifluorescence microscope. Nikon UV-2B, DM505 and G-2A filter sets were used for bacteria and heterotrophic flagellates, for picocyanobacteria and for autotrophic flagellates, respectively. At least 200 bacteria and 100 flagellate cells were counted from each sample. Ciliates and copepod nauplii were preserved with Bouin's solution (2\% final conc.). All samples were kept cold and in the dark until processed. Ciliates and copepod nauplii were counted and identified using settled volumes on an inverted microscope. Zooplankton and phytoplankton samples were preserved with formaldehyde ( $2 \%$ final conc.). They were also kept cold and in the dark, settled and then counted with an inverted microscope. Zooplankton fecal pellets were also counted as an indication of feeding pressure. Phytoplankton community data were reduced for statistical analysis by principal component analysis (PCA, Statview).

Bacterial activity was measured with the thymidine incorporation method according to Smith \& Azam (1993) with modifications as follows. Three $1 \mathrm{ml} \mathrm{sam-}$ ples from each container were pipetted into $2.0 \mathrm{ml}$ microcentrifuge tubes containing tritiated $\left({ }^{3} \mathrm{H}\right)$ thymidine to achieve a final concentration of $20 \mathrm{nM}$. Three 
additional samples were killed with formaldehyde ( $1.3 \%$ final conc.) to serve as controls. The samples were incubated for $45 \mathrm{~min}$ in ambient conditions, after which $1 \mathrm{ml}$ of ice-cold trichloroacetic acid (TCA: 10\% final conc.) was added to stop the incubations and to precipitate the macromolecules. The samples were centrifuged and the pellets sequentially rinsed with $1 \mathrm{ml}$ each of $5 \%$ TCA and $70 \%$ ethyl alcohol. Liquid scintillation cocktail was then added and the radioactivity of the samples was measured with a Wallac 1409 scintillation counter.

Pigment samples were collected on Whatman GF/F filters and frozen until analyzed by HPLC. For HPLC analysis, filter pads were extracted in methanol buffered with $2 \% 0.5 \mathrm{M}$ ammonium acetate buffer at $\mathrm{pH} 7.2$ by sonication at $50 \mathrm{~W}$ for $30 \mathrm{~s}$. Extracts were analyzed following the method of Wright et al. (1991) using a Hewlett Packard 1090 HPLC with a tertiary gradient elution system, and a $250 \times 4 \mathrm{~mm}$ Spherisorb $5 \mu \mathrm{m}$ ODS 2 column. A photodiode array detector was used to collect absorbance data from 350 to $500 \mathrm{~nm}$. Data were processed using a Hewlett Packard Chem Station. The instrument was calibrated for analysis of the following pigments: chlorophyll $a$ (chl $a$ ), chl $b$, chls $c_{1}$ and $c_{2}$, alloxanthin, butanoyloxyfucoxanthin, diadinoxanthin, diatoxanthin, divinylpheo-porphyrin $a_{5}$ fucoxanthin, 19'-hexanoyloxyfucoxanthin, lutein, monado-xanthin, myxoxanthophyll, neoxanthin, nostoxanthin, peridinin, prasinoxanthin, violaxanthin, and zeaxanthin.

BIOLOG ECO Microplates containing 31 different sole carbon sources were used to compare metabolic activity patterns of bacterial assemblages between treatments. Samples were removed immediately after setup and at the end of the experiment $(74 \mathrm{~h})$. After samples $(100 \mu \mathrm{l})$ were added to each well, the plates were incubated at room temperature and monitored for reduction of the indicator dye. The pattern of sole carbon source use was recorded after no further changes were detected over a $24 \mathrm{~h}$ period. Plate images were digitized on a flat bed scanner and the chemical reduction, as colorimetric density, was quantified using NIH Image 1.60. The threshold function was used to subtract control (water only) wells from all treatment wells. Any resulting negative values were recorded as zero. Data matrices were reduced for statistical analysis by principal components analysis (Statview).

The community growth rate constants for different ciliate types and for copepods (dominated by Acartia tonsa) were determined from population counts in the copepod removal containers. These estimates integrated mortality and any limitations on the populations inherent to the experimental setup to provide estimates of growth rates. Regression analysis of natural logarithm-transformed cell numbers was used to obtain the slopes of linear portions of growth events by the equation:

$$
\mu=\left(\ln N_{t f}-\ln N_{t 0}\right) / \Delta t
$$

where $N_{t \mathrm{f}}=$ the number of individuals at the end of a time interval, $N_{t 0}=$ the number of individuals at the beginning of a time interval and $\Delta t=$ the time interval.

Differences between treatments were analyzed with repeated-measures ANOVA (Generalized Linear Model [GLM], Version 8.02, SAS Institute 1996) with time as a within-subject factor and treatment as a between-subjects factor. The differences between treatments in BIOLOG data were analyzed by doubly multivariate ANOVA, and phytoplankton community structure with MANOVA, with first and second principal components (PCA, Statview) used as the response variables. The assumption of normality was tested by evaluating the residuals (error terms) of the (M)ANOVA model by Shapiro-Wilks test (Proc Univariate, Version 8.02, SAS Institute 1996). The homogeneity of variances was verified by analyzing the residuals with the same model as with which the actual analysis was performed. Values were $\ln (x+1)$-transformed when necessary.

\section{RESULTS}

The copepod removal treatment was effective, and resulted in significant differences in copepod and nauplii numbers between the treatments for the first $39 \mathrm{~h}$ (Fig. 1a, Table 1). In the addition treatment, the copepod numbers declined over time, presumably from starvation due to depletion of phytoplankton and ciliates (see phytoplankton and microzoooplankton results below). After $15 \mathrm{~h}$, nauplii numbers in the addition treatment also declined and remained at the same level in both treatments until the end of the experiment. In the removal treatment, adult copepod numbers increased exponentially (Fig. 1a,b, Table 2). The density of copepod fecal pellets reflected the grazing activity of the copepods and confirmed that the experimental manipulation altered the feeding pressure on the microbial plankton (Fig. 1c, Table 1).

Diatoms dominated the phytoplankton community in both treatments (Fig. 2). Although the total phytoplankton biomass at the $50 \mathrm{~h}$ time point was similar in both treatments, in comparison the community structure was statistically different from both the initial conditions and the copepod removal treatment (Table 3 , PCA data not shown). Where copepods were removed, phytoplankton increased uniformly with little change in the species proportions (Fig. 2). In the copepod addition treatment, the phytoplankton assemblage was less 

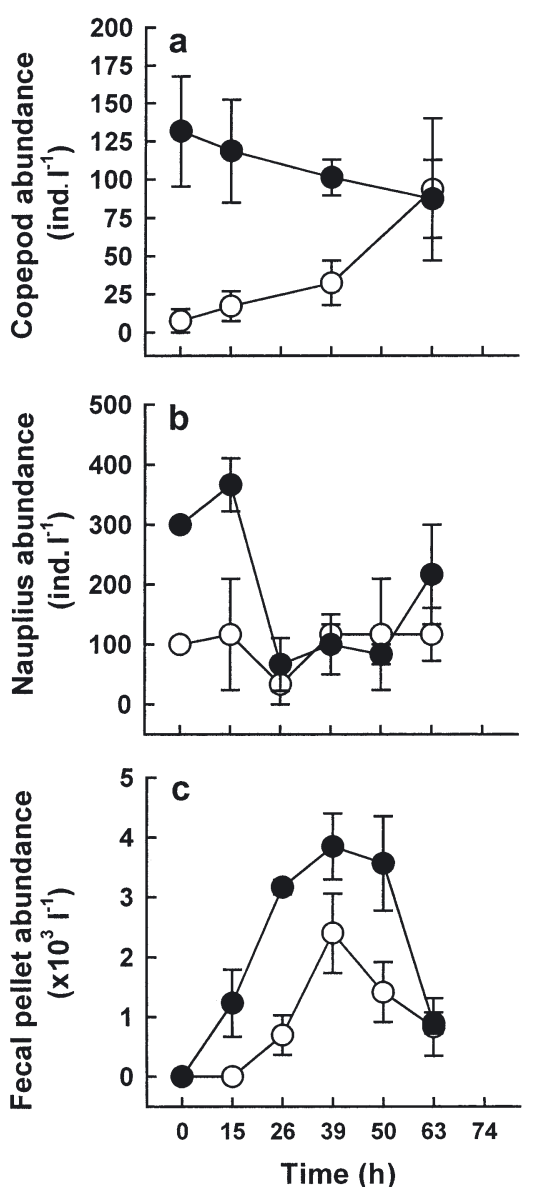

Fig. 1. Mean abundances $( \pm \mathrm{SE})$ of (a) copepods, (b) copepod nauplii and (c) copepod fecal pellets in copepod removal (O) and copepod addition $(\bullet)$ treatments
Table 2. Acartia tonsa and ciliate community growth rates in the copepod removal treatment. $\mu=$ specific growth rate, $T_{D}=$ doubling time $(\mathrm{h})$

\begin{tabular}{|lccr|}
\hline Species & $\mu$ & $\mathrm{SE}$ & $\mathrm{T}_{\mathrm{D}}$ \\
\hline Acartia tonsa adult population & 0.038 & 0.004 & 18.24 \\
Large Strombidinopsis sp. & 0.111 & 0.020 & 6.24 \\
Strobilidium sp. & 0.167 & 0.034 & 4.15 \\
Tintinnopsis minuta & 0.144 & 0.023 & 4.71 \\
Small Strombidium sp. & 0.160 & 0.009 & 4.33 \\
\hline
\end{tabular}

Table 3. (a) MANOVA for phytoplankton community structure at the $50 \mathrm{~h}$ time point with 1st and 2nd principal components (PC 1 and 2) as the response variables. (b) Univariate ANOVA for the 1st and 2nd principal components. TR = treatment, Num $\mathrm{df}=$ numerator $\mathrm{df}$, Den $\mathrm{df}=$ denominator $\mathrm{df}$

\begin{tabular}{|lccccccc|}
\hline (a) & Num df & Den df & Value & $F$ & $\mathrm{p}$ \\
\hline TR & \multicolumn{2}{c}{2} & 3 & & 57.55 & 86.33 & 0.002 \\
(b) & df & Error df & MS & Error MS & $F$ & $\mathrm{p}$ \\
\hline PC 1 & 1 & 4 & 0.004 & 0.013 & 0.320 & 0.604 \\
PC 2 & 1 & 4 & 1.455 & 0.032 & 58.44 & 0.002 \\
\hline
\end{tabular}

diverse; very large centric diatoms (ESD $>200 \mu \mathrm{m})$ and an epizoic diatom (Falcula sp.) benefited from copepod presence, while other species declined. Chl a concentrations increased significantly more in the copepod removal treatment (Fig. 3a, Table 1). Silicoflagellates increased in both treatments, but significantly more so in the copepod removal treatment (Fig. 4e, Table 1).

Table 1. Repeated measures ANOVA for the effect of time and treatment (copepod presence) on the response variables. FP = fecal pellets, $\mathrm{CS}=$ cell-specific, prod. = production, total $\mathrm{C}$ sources = total number of BIOLOG carbon sources utilized by bacteria, $\mathrm{HNF}=$ heterotrophic nano-flagellates, $\mathrm{ANF}=$ autotrophic nanoflagellates, $\mathrm{df}=$ degrees of freedom for the factors time and time $\times$ treatment. For the factor treatment, df is 1 for all variables. Error df (treatment, time)

\begin{tabular}{|c|c|c|c|c|c|c|c|c|c|c|c|c|c|}
\hline & \multirow[t]{2}{*}{$\mathrm{df}$} & \multirow{2}{*}{$\begin{array}{c}\text { Error } \\
\text { df }\end{array}$} & \multicolumn{4}{|c|}{ - Treatment } & \multicolumn{4}{|c|}{$\ldots$ Time } & \multicolumn{3}{|c|}{ Time $\times$ Treatment } \\
\hline & & & MS & Error MS & $F$ & $\mathrm{p}$ & MS E & Error MS & $F$ & $\mathrm{p}$ & MS & $F$ & $\mathrm{p}$ \\
\hline Copepods & 3 & 4,12 & 31.10 & 2.774 & 11.21 & 0.029 & 0.748 & 1.157 & 0.650 & 0.600 & 4.842 & 4.180 & 0.030 \\
\hline Nauplii & 5 & 4,20 & 71.11 & 20.28 & 3.510 & 0.134 & 30.28 & 6.194 & 4.890 & 0.004 & 20.28 & 3.270 & 0.026 \\
\hline Copepod FP & 5 & 4,20 & 13.57 & 1.661 & 8.160 & 0.046 & 8.692 & 0.327 & 26.56 & $<0.000$ & 1.587 & 4.850 & 0.005 \\
\hline Bacterial numbers & 6 & 4,24 & 1.332 & 0.105 & 12.63 & 0.024 & 1.483 & 0.454 & 3.270 & 0.017 & 2.232 & 4.920 & 0.002 \\
\hline CS bacterial prod. & 6 & 4,24 & 80.79 & 1.907 & 42.37 & 0.003 & 11.53 & 0.848 & 13.60 & $<0.000$ & 2.091 & 2.470 & 0.053 \\
\hline Total C sources & 1 & 4,4 & 12.03 & 0.567 & 21.24 & 0.010 & 40.83 & 1.033 & 39.52 & 0.003 & 17.63 & 17.60 & 0.015 \\
\hline Picocyanobacteria & 6 & 4,24 & 0.072 & 2.581 & 0.030 & 0.875 & 40.02 & 1.101 & 36.34 & $<0.000$ & 3.053 & 2.770 & 0.034 \\
\hline HNF & 6 & 4,24 & 0.661 & 0.227 & 2.910 & 0.163 & 2.127 & $7 \quad 0.156$ & 13.65 & $<0.000$ & 0.939 & 6.020 & 0.001 \\
\hline ANF & 6 & 4,24 & 2.710 & 0.106 & 2.550 & 0.186 & 5.043 & 0.589 & 8.560 & $<0.000$ & 2.795 & 4.750 & 0.003 \\
\hline Ciliates & 5 & 4,20 & 53.28 & 0.973 & 54.76 & 0.002 & 0.774 & $4 \quad 0.283$ & 2.730 & 0.049 & 3.765 & 13.30 & $<0.000$ \\
\hline Silicoflagellates & 5 & 4,20 & 1.210 & 0.057 & 21.07 & 0.010 & 1.253 & 30.063 & 19.92 & $<0.000$ & 0.254 & 4.030 & 0.011 \\
\hline Chl a & 2 & 4,8 & 3.308 & 30.102 & 32.43 & 0.005 & 4.608 & 30.069 & 67.06 & $<0.000$ & 3.512 & 51.12 & $<0.000$ \\
\hline Chl $C$ & 2 & 4,8 & 0.545 & 0.372 & 1.460 & 0.293 & 9.753 & 30.372 & 26.22 & $<0.000$ & 0.545 & 1.460 & 0.287 \\
\hline Zeaxanthin & 2 & 4,8 & 1.566 & 0.129 & 12.13 & 0.025 & 4.085 & 0.080 & 50.82 & $<0.000$ & 1.970 & 24.51 & $<0.000$ \\
\hline Fucoxanthin & 2 & 4,8 & 0.099 & 0.081 & 1.190 & 0.336 & 2.565 & 50.069 & 37.36 & $<0.000$ & 0.692 & 10.07 & 0.007 \\
\hline
\end{tabular}


Fig. 2. Mean total biomass of phytoplankton divided into taxonomic groups. + = zooplankton addition treatment, - = zooplankton removal treatment. SE of the total biomass is given above each bar. The $t=0(0 \mathrm{~h})$ sample is composite for both treatments
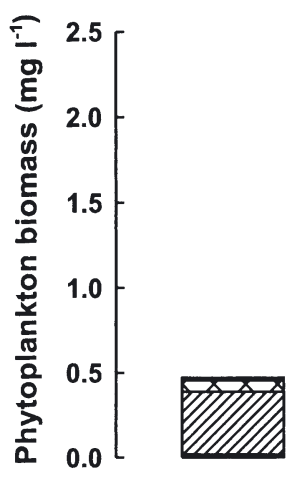

Oh

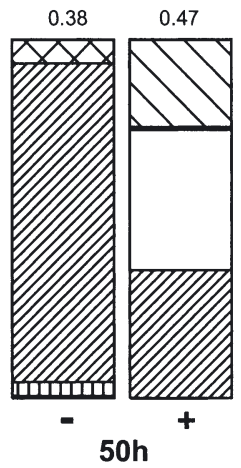

Results of HPLC analyses indicated that chl $C$, fucoxanthin and zeaxanthin were the only accessory pigments present in significant quantities. These pigments are representative of diatoms and dinoflagellates (chl $c_{2}$ and fucoxanthin), and cyanobacteria (zeaxanthin in the absence of chl $b$ ). The absence of 19-substituted fucoxanthin suggests the absence of prymnesiophytes and chrysophytes, which could also be indicated by the presence of chl $c$ and fucoxanthin. However, the absence of peridinin cannot be used to rule out dinoflagellates since many species do not contain peridinin (Jeffery et al. 1997). Fucoxanthin and zeaxanthin increased significantly less in the zooplankton addition treatment relative to the zooplankton removal treatment (Fig. 3, Table 1). Chl c concentration did not differ between treatments, but the time effect was significant due to the increase in all enclosures (Fig. 3, Table 1).

Microzooplankton consisted mainly of ciliates; data on other minor constituent groups are not presented. Ciliate numbers differed between treatments (significant treatment and time $\times$ treatment effects; see Table 1 ). Ciliates were depleted by the first sampling point at $15 \mathrm{~h}$ after the copepod addition, and remained at a low level in this treatment until the end of the experiment (Fig. 4f). In the copepod removal treatment, ciliate numbers increased exponentially during the first $26 \mathrm{~h}$ (Table 2), but declined rapidly after $39 \mathrm{~h}$ coincident with the rebound of the adult copepod population. Numerical responses of small oligotrichids and tintinnids that dominated the copepod removal incubations were similar (Table 2).

Heterotrophic nanoflagellates were more abundant than autotrophic flagellates. There were no statistically significant overall differences between the treatments, but the temporal changes in numbers were different between autotrophic and heterotrophic flagellates (Fig. 4d), and between the treatments in both groups (significant time $\times$ treatment effects; see Table 1).

Picocyanobacteria numbers increased in both treatments during the first $15 \mathrm{~h}$ of the experiment, and then declined (significant time effect; see Table 1, Fig. 4c). However, the initial increase was more pronounced in the copepod removal treatment (significant time $\times$ treatment effect; see Table 1).

Heterotrophic bacteria responded positively to the copepod addition in many respects. The copepod addition treatment resulted in a fast increase of bacterial
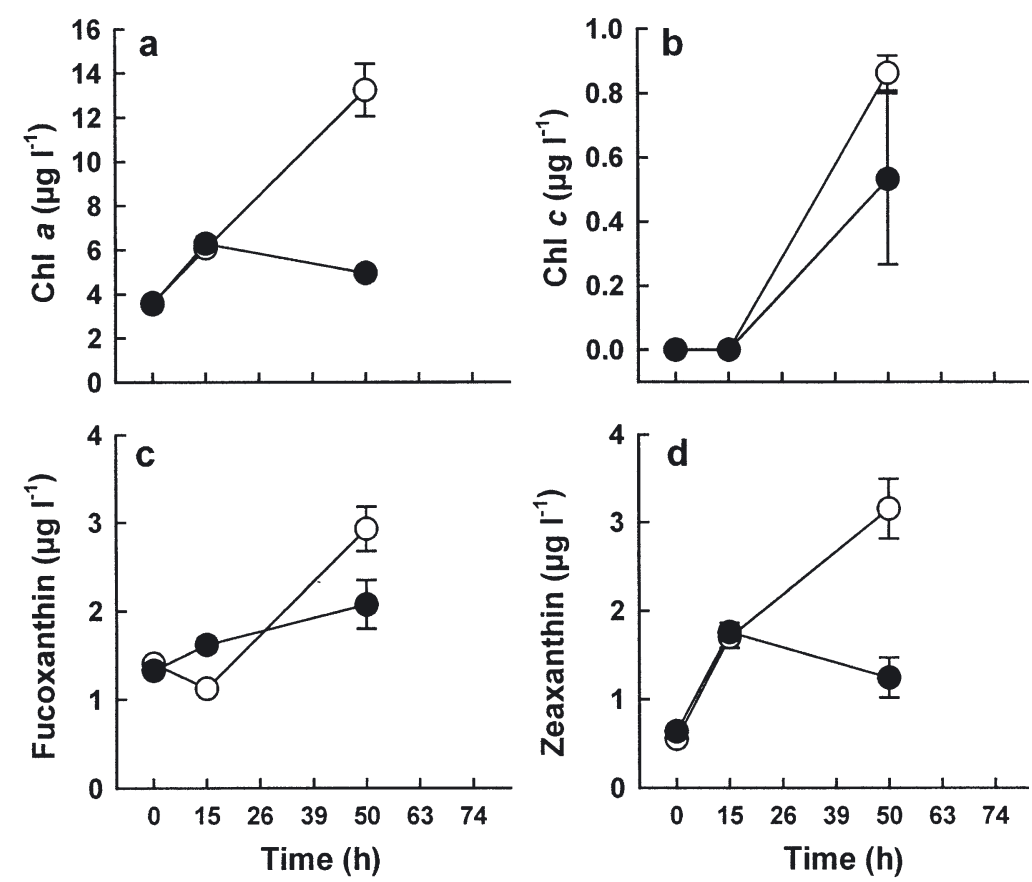

Fig. 3. Mean concentrations $( \pm \mathrm{SE})$ of (a) $\operatorname{chl} a_{1}$ (b) chl $c_{r}$ (c) fucoxanthin and $(d)$ zeaxanthin in copepod removal $(0)$ and copepod addition $(\bullet)$ treatments 

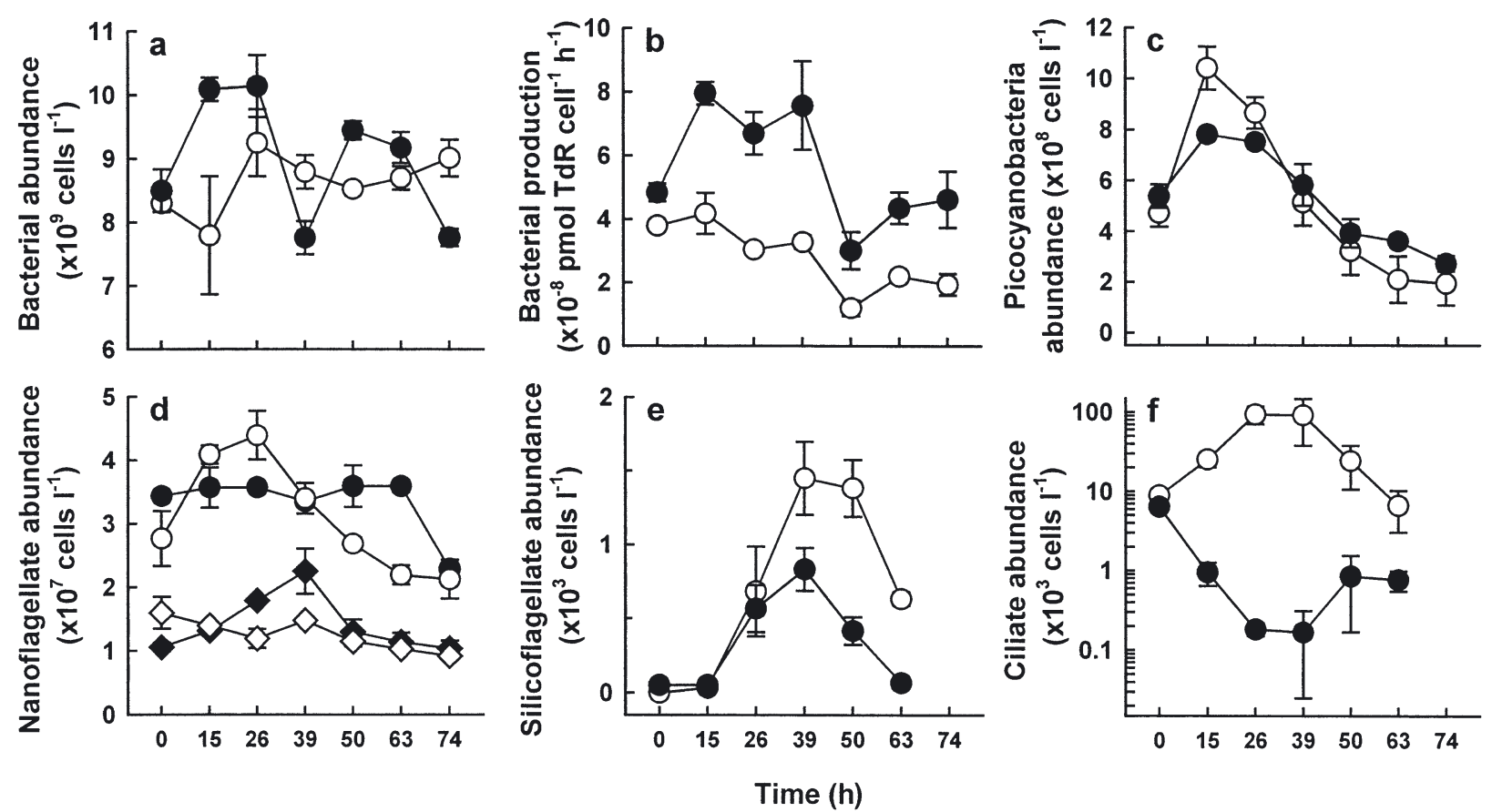

Fig. 4. Abundances of (a) bacteria, (c) picocyanobacteria, (d) heterotrophic (circle) and autotrophic (diamond) flagellates, (e) silicoflagellates and (f) ciliates; (b) cell-specific bacterial production. Copepod removal and copepod addition treatments indicated by open and filled symbols, respectively. Mean values $( \pm \mathrm{SE})$ are shown. TdR $=$ thymidine

numbers, whereas the numbers in the removal treatment remained close to original levels (Fig. 4a). After the initial increase, numbers in the copepod addition treatment declined. The difference between treatments was significant (significant treatment and time $\times$ treatment effects; see Table 1).

The bacterial activity (determined by thymidine incorporation) responded positively, and very strongly, to the copepod addition treatment (significant treatment effect; see Table 1, Fig. 4b). Normalizing the production rates of bacteria by their abundance shows the same initial increase as the total bacterial activity (data not shown), indicating a true increase in cell-specific pro-

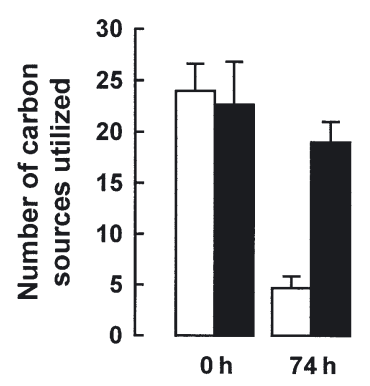

Fig. 5. Mean $( \pm \mathrm{SE})$ numbers of BIOLOG carbon sources utilized by the bacterial assemblages in copepod removal (white bars) and copepod addition (black bars) treatments duction. Assuming a carbon content of $2.5 \mu \mathrm{g}$ per copepod (Huntley \& Lopez 1992), a $20 \%$ growth efficiency for the bacteria, $0.5 \mathrm{fg}$ carbon per bacterial cell (Snyder \& Hoch 1996) and a thymidine conversion factor of $2 \times 10^{18}$ cells per mole of thymidine (Robarts \& Zohary 1993), the increase in bacterial production could be accounted for by the death of copepods in the copepod addition treatment. Bacterial production did not respond to the bloom of diatoms and microzooplankton that occurred in the copepod removal treatment (Fig. 4b).

At the beginning of the experiment, bacterial response time and the total number of carbon sources used in the BIOLOG plates was similar in both treatments (Fig. 5). Also, the principal component scores clustered together indicating similarity of the bacterial communities despite the manipulations used to set up the experiment (PCA data not shown). Bacterial response to BIOLOG assays became different between the treatments during the incubations, indicating a copepod effect concomitant with increased bacterial activity. The total number of carbon sources used differed significantly between treatments (Table 1). The speed of dye reduction was much faster in the copepod addition treatment ( $\sim 12 \mathrm{vs} \sim 48 \mathrm{~h})$ reflecting the total bacterial activity measured by thymidine incorporation. The time $\times$ treatment effect was significant in the repeated measures ANOVA analysis of the first PCA axis (Table 4b). 
Table 4. (a) Multivariate repeated measures ANOVA for BIOLOG physiological bacterial community structure with 1st and 2nd principal components (PC 1 and 2 ) as the response variables. (b) Univariate repeated measures ANOVA for the 1st and 2nd principal components. $\mathrm{TR}=$ treatment, $\mathrm{TI}=$ time, Num $\mathrm{df}=$ numerator $\mathrm{df}$, Den $\mathrm{df}=$ denominator $\mathrm{df}$

\begin{tabular}{|c|c|c|c|c|c|c|c|}
\hline (a) & \multicolumn{2}{|c|}{ Num df } & Den df & Value & \multicolumn{2}{|c|}{$F$} & $\mathrm{p}$ \\
\hline TR & \multicolumn{2}{|c|}{2} & 3 & 1.076 & \multicolumn{2}{|c|}{1.614} & 0.334 \\
\hline TI & \multicolumn{2}{|c|}{2} & 3 & 8.938 & \multicolumn{2}{|c|}{13.41} & 0.032 \\
\hline $\mathrm{TI} \times \mathrm{TR}$ & \multicolumn{2}{|c|}{2} & 3 & 2.329 & \multicolumn{2}{|c|}{3.494} & 0.165 \\
\hline (b) & & $\mathrm{df}$ & Error df & MS & Error MS & $F$ & $\mathrm{p}$ \\
\hline \multirow[t]{3}{*}{ PC 1} & TR & 1 & 4 & 0.174 & 0.053 & 3.28 & 0.144 \\
\hline & TI & 1 & 4 & 0.156 & 0.014 & 11.5 & 0.027 \\
\hline & $\mathrm{TI} \times \mathrm{TF}$ & 1 & & 0.127 & & 9.31 & 0.038 \\
\hline \multirow[t]{3}{*}{ PC 2} & TR & 1 & 4 & 0.104 & 0.156 & 0.66 & 0.461 \\
\hline & TI & 1 & 4 & 0.547 & 0.044 & 12.3 & 0.025 \\
\hline & $\mathrm{TI} \times \mathrm{TF}$ & 1 & & 0.041 & & 0.92 & 0.391 \\
\hline
\end{tabular}

\section{DISCUSSION}

\section{Acartia tonsa growth and mortality}

The copepod removal/addition treatment was effective in establishing the initial conditions of the experiment. Copepod removal permitted monitoring the response of microbial plankton to release from copepod predation pressure as well as the effects of the recovery of the adult copepod population. Copepod nauplii numbers followed the manipulated numbers of adult copepods, making the impact of nauplii that escaped the filtration process coincident with the impact of the adult copepod manipulations.

The mortality of Acartia tonsa in the copepod addition treatment was likely triggered by starvation. The density of copepods added in this experiment was within the range found for the source environment (Lores et al. 2002), and available prey was largely depleted by the $12 \mathrm{~h}$ sampling point. The observed mortality rate agrees with direct measurements of $A$. tonsa mortality under starvation (Dagg 1977). The fecal pellet counts also indicated more intensive copepod grazing activity in the addition treatment, coincident with the loss of prey populations. In the copepod removal treatment, $A$. tonsa adult numbers recovered by growth of eggs and nauplii that passed through the filtration process. A. tonsa at $30^{\circ} \mathrm{C}$ can develop from egg to egg-producing adults in 3.5 to 4 d (Mauchline et al. 1998). The rapid copepod growth in the removal treatment also suggests that the experimental conditions, other than starvation due to confinement, did not cause the observed mortality in the addition treatment.

\section{Direct Acartia tonsa trophic interactions}

When Acartia tonsa was added to the containers, the rapid removal of ciliates and phytoplankton was nearly complete and sustained, despite decreasing copepod numbers. Where $A$. tonsa was removed, the biomass of ciliates increased rapidly. This increase occurred in the presence of some naupliar stages of copepods, which may have reduced the observed growth responses of the ciliates (Table 2). The recovery of the adult copepod population in the initial removal treatment was concomitant with a reduction of the ciliates, consistent with the initial effect in the copepod addition treatment. Phytoplankton pigment concentrations responded similarly but more slowly. The greater increase in $\mathrm{chl} C$, diadinoxanthin and fucoxanthin in the copepod removal treatment was an indicator of the reduced copepod grazing on diatoms and dinoflagellates. These pronounced responses in phytoplankton and ciliates, induced by addition or removal of copepods, reveal the strength of these trophic relationships (sensu Paine 1980), and imply potential for short-term cascading effects in this experimental system.

Acartia tonsa, and calanoid copepods in general, can feed omnivorously on both phytoplankton and microzooplankton (e.g. Kleppel 1993). However, Turner et al. (2001) found a feeding preference on oligotrichous ciliates rather than co-occurring phytoplankton. Prey limitation or starvation may result in non-specific feeding as observed in the current experiment. For example, the larger increase in silicoflagellate numbers in the copepod removal treatment after $26 \mathrm{~h}$ suggests that copepods fed on silicoflagellates where ciliate and edible phytoplankton numbers had decreased. The increase in silicoflagellate numbers in both treatments indicates, in addition to favorable incubation conditions, some measure of protection from copepod attack.

Large Coscinodiscus sp. (200 $\mu \mathrm{m}$ ESD) was not eaten by Acartia tonsa, and judging from its increase in the copepod addition treatment, was probably near or above the upper prey size limit of the latter. This agrees with Berggren et al. (1988), who found that the maximum size for prey capture by adult $A$. tonsa was $250 \mu \mathrm{m}$ ESD. Most ciliates fall well within the optimum prey size range, i.e. 14 to $70 \mu \mathrm{m} \mathrm{ESD,} \mathrm{for}$ the late developmental stages of $A$. tonsa (Berggren et al. 1988). 


\section{Indirect Acartia tonsa effects}

The impact of copepod grazing on ciliates had potential for a flagellate response as the overall ciliate grazing rate was reduced, but a corresponding change in nanoflagellate numbers was not observed. In fact, autotrophic and heterotrophic flagellate responses were small and different from each other, which is not in accordance with a strong, uniform change in predation pressure. This lack of cascading predation effect is compatible with other studies of microbial plankton dynamics (e.g. Pace \& Funke 1991, Jeppesen et al. 1998). Several mechanisms may explain these patterns.

Cross-linkages between flagellate predators (ciliates and copepods) could have been balanced (e.g. Pace \& Cole 1996), leading to zero net effect. Pace et al. (1998) suggested this in studies of Daphnia impacts on lake plankton. However, Acartia tonsa has relatively lower grazing rates on nano-sized prey (Jürgens 1994) with a lower limit of 2 to $4 \mu \mathrm{m}$ ESD for all developmental stages, including nauplii (Berggren et al. 1988, but see Turner \& Tester 1992), which makes the cross-linkage hypothesis less likely in this situation.

Cross-linkage could have occurred between ciliates and flagellates (Rassoulzadegan et al. 1988). Ciliates may have acted as competitors with predatory flagellates (e.g. Calbert et al. 2001), thus dampening the overall flagellate response as well as the responses of their common pico-sized prey. If ciliates efficiently depressed flagellate-preying flagellates, then they released other flagellates from predation. Flagellate species could not be identified in this study, and therefore data were not obtained on any nanoplankton community composition changes that might have occurred in support of this concept. Alternatively, the lack of flagellate response to the copepod manipulation could indicate that the ciliates did not include a species or guild capable of strong interactions with flagellate prey when ciliates were relieved from copepod predation (see Power 1990, 1992). Large microzooplankton species with a potentially greater grazer impact on nanoplankton were not as numerically dominant as smaller ciliates in this short-term experiment.

Another possibility is that the lower trophic levels are not regulated as much by consumers, as by resources in all but very eutrophic situations, where predation becomes important (Pace \& Funke 1991). In this study, bacterial numbers (and production) did show a fast positive response to copepod addition, indicating an increase in resources. Picocyanobacteria growth, on the other hand, was more pronounced in the copepod removal treatment. This could have been due to a shift in competition between bacteria and picocyanobacteria in the different treatments (Drakare
2002). While the bacterial production stayed high, the numerical responses of bacteria and picocyanobacteria were short-lived. This makes the resource regulation hypothesis inadequate for explaining the observed changes. Increased mortality apparently caught up with increased production very quickly. This implies a balance between increased predation and recycling of resources by consumers as a plausible mechanism explaining the dynamics of bacteria and picocyanobacteria numbers in this experiment (Snyder \& Hoch 1996, Mikola \& Setälä 1998, Carpenter et al. 2001).

In addition to an increase in bacterial activity, the metabolic patterns in response to copepod manipulation also suggest resource effects of copepods on bacteria. The BIOLOG analysis used in this experiment does not distinguish between differences in physiological state and diversity of the bacterial community. However, it does give a measure of community metabolic response and the diversity of substrates being processed from a systems point of view. The number of utilized carbon sources declined only slightly with time in the copepod addition treatment, but dropped steeply with time in the presence of a diatom bloom where copepods were removed, indicative of bacterial starvation. The apparent starvation of the bacteria in the presence of a diatom bloom in this experiment supports the hypothesis of copepod grazing acting as a link from primary production to bacterial production (Roman et al. 1988, Vadstein et al. 1989, Peduzzi \& Herndl 1992), rather than bacterial production being directly supported by 'leaky phytoplankton' (Fuhrman et al. 1980, 1985, Brock \& Clyne 1984, Søndergaard et al. 1985).

\section{CONCLUSIONS}

Acartia tonsa feeding had pronounced effects on phytoplankton and ciliate abundances, but these effects did not impact smaller size-classes of microbial plankton. The same conclusions have been drawn for Daphnia-dominated systems, where nanoplankton biomass changes appear to be insulated from higher trophic level predation impacts (Pace et al. 1998). In this respect, Daphnia and A. tonsa may function similarly. However, the smaller lower size limit for prey capture in Daphnia probably causes its grazing activity to affect a wider size range of species directly. While elucidation and quantification of trophic interactions within nanoplanktonic organisms remains unresolved, trophic heterogeneity and cross linkages seem plausible explanations for the lack of recorded nanoplankton response in our experiment. Although bacterioplankton response was confounded by the availability of 
substrates from dying copepods, the starvation of bacteria in the presence of a diatom bloom suggests that the short-term effects of $A$. tonsa feeding activity can affect both the largest (micro-) and smallest (pico-) components of the microbial plankton directly.

Acknowledgements. We would like to thank J. Moss for help with microzooplankton counts, H. Simola for assistance in diatom taxonomy and A. Lagus, J. Suomela and K. Vuorio for valuable comments on the manuscript. This study was supported by the Academy of Finland (grant no. 44130).

\section{LITERATURE CITED}

Berggren U, Hansen B, Kiørboe T (1988) Food size spectra, ingestion and growth of the copepod Acartia tonsa during development: implications for determination of copepod production. Mar Biol 99:341-352

Bird DF, Kalff J (1984) Empirical relationships between bacterial abundance and chlorophyll concentration in fresh and marine waters. Can J Fish Aquat Sci 41:1015-1023

Brock TD, Clyne J (1984) Significance of algal excretory products for growth of epilimnetic bacteria. Appl Environ Microbiol 47:731-734

Calbert A, Landry MR, Nunnery S (2001) Bacteria-flagellate interactions in the microbial food web of the oligotrophic subtropical North Pacific. Aquat Microb Ecol 23:283-292

Carpenter SR, Kitchell JF, Hodgson JR (1985) Cascading trophic interactions and lake productivity. BioScience 35: $634-639$

Carpenter SR, Cole JJ, Hodgson JR, Kitchell JF and 6 others (2001) Trophic cascades, nutrients, and lake productivity: whole lake experiments. Ecol Monogr 71:163-186

Cole JJ, Findlay S, Pace ML (1988) Bacterial production in fresh and saltwater ecosystems: a cross-system overview. Mar Ecol Prog Ser 43:1-10

Dagg M (1977) Some effects of patchy food environments on copepods. Limnol Oceanogr 22:99-107

Dolan J, Gallegos CL (1991) Trophic coupling of rotifers, microflagellates, and bacteria during fall months in the Rhode River estuary. Mar Ecol Prog Ser 77:147-156

Drakare S (2002) Competition between picoplanktonic cyanobacteria and heterotrophic bacteria along crossed gradients of glucose and phosphate. Microb Ecol 44:327-335

Fuhrman JA, Ammerman JW, Azam F (1980) Bacterioplankton in the coastal euphotic zone: distribution, activity and possible relationships with phytoplankton. Mar Biol 60: 201-207

Fuhrman JA, Eppley RW, Hagström ^̊, Azam F (1985) Diel variations in bacterioplankton, phytoplankton, and related parameters in the Southern California Bight. Mar Ecol Prog Ser 27:9-20

Gismervik I, Andersen T, Vadstein O (1996). Pelagic food webs and eutrophication of coastal waters: impact of grazers on algal communities. Mar Pollut Bull 33:22-35

Hairston NG, Smith FE, Slobodkin LB (1960) Community structure, population control, and competition. Am Nat 94 : 421-425

Hallegraeff GM (1993) A review of harmful algal blooms and their apparent global increase. Phycologia 32:79-99

Huntley ME, Lopez MDG (1992) Temperature-dependent production of marine copepods - a global synthesis. Am Nat 140:201-242

Jeffery SW, Mantoura RFC, Wright SW (eds) (1997) Phyto- plankton pigments in oceanography. Monographs on oceanographic methods. UNESCO, Paris

Jeppesen E, Søndergaard M, Jensen JP, Mortensen E, Hansen AM, Jorgensen T (1998) Cascading trophic interactions from fish to bacteria and nutrients after reduced sewage loading: an 18-year study of a shallow hypertrophic lake. Ecosystems 1:250-267

Jumars PA, Penry DL, Baross JA, Perry MJ, Frost B (1989) Closing the microbial loop: dissolved carbon pathway to heterotrophic bacteria from incomplete ingestion, digestion and absorption in animals. Deep-Sea Res Part A 36: 483-495

Jürgens K (1994) Impact of Daphnia on planktonic microbial food webs - a review. Mar Microb Food Webs 8:295-324

Kleppel GS (1993) On the diets of calanoid copepods. Mar Ecol Prog Ser 99:183-195

Lores EM, Lewis MA, Malaeb ZA (2002) Spatial and temporal variability in zooplankton community dynamics in three urbanized bayous of the Pensacola Bay System, Florida, USA. Gulf Caribb Res 14:1-11

Mauchline J, Blaxter JHS, Southward AJ, Tyler PA (1998) Biology of calanoid copepods. In: Blaxter JHS, Southward AJ, Tyler PA (eds) Advances in marine biology, Vol 33. Academic Press, San Diego, CA

Mikola J, Setälä H (1998) No evidence of trophic cascades in an experimental microbial-based soil food web. Ecology 79:153-164

Nixon SW (1995) Coastal marine eutrophication, social causes and future concerns. Ophelia 41:199-220

Pace ML, Cole JJ (1996) Regulation of bacteria by resources and predation tested in whole-lake experiments. Limnol Oceanogr 41:1448-1460

Pace ML, Funke E (1991) Regulation of planktonic microbial communities by nutrients and herbivores. Ecology 72 : 904-914

Pace ML, Cole JJ, Carpenter SR (1998). Trophic cascades and compensation: differential responses of microzooplankton in whole-lake experiments. Ecology 79:138-152

Paine RT (1980) Food webs: linkage, interaction strength and community infrastructure. J Anim Ecol 49:667-685

Pearl HW, Whittall DR (1999) Anthropogenically-driven atmospheric nitrogen deposition, marine eutrophication and harmful algal bloom expansion: is there a link? Ambio 28:307-311

Peduzzi P, Herndl GJ (1992) Zooplankton activity fueling the microbial loop: differential growth response of bacteria from oligotrophic and eutrophic waters. Limnol Oceanogr 37:1087-1092

Polis GA (1999) Why are parts of the world green? Multiple factors control productivity and the distribution of biomass. Oikos 86:3-15

Polis GA, Sears ALW, Huxel GR, Strong DR, Maron J (2000) When is a trophic cascade a trophic cascade? Trends Ecol Evol 15:473-475

Porter KG, Feig YS (1980) Use of DAPI for identifying and counting aquatic microflora. Limnol Oceanogr 25:943-948

Power ME (1990) Effects of fish in river food webs. Science 250:411-415

Power ME (1992) Top-down and bottom-up forces in food webs: Do plants have primacy? Ecology 73:733-746

Rassoulzadegan F, Laval-Peuto M, Sheldon RW (1988) Partitioning of the food ration of marine ciliates between picoand nanoplankton. Hydrobiologia 159:75-88

Robarts RD, Zohary T (1993) Fact or fiction - bacterial growth rates and production as determined by $\left[\right.$ methyl- $\left.{ }^{3} \mathrm{H}\right]-$ Thymidine? Adv Microb Ecol 13:371-425

Roman MR, Ducklow HW, Fuhrman JA, Garside C, Gilbert 
PM, Malone TC, McManus GB (1988) Production, consumption and nutrient cycling in a laboratory mesocosm. Mar Ecol Prog Ser 42:39-52

Smith DC, Azam F (1993) A simple, economical method for measuring bacterial protein synthesis rate in seawater using tritiated-leucine. Mar Microb Food Webs 6(2): 107-114

Snyder RA, Hoch MP (1996) Consequences of protist-stimulated bacterial production for estimating protist growth efficiencies. Hydrobiology 341:113-123

Søndergaard M, Riemann B, Jørgensen NOG (1985) Extracellular organic carbon (EOC) released by phytoplankton and bacterial production. Oikos 45:323-332

Strong DR (1992) Are trophic cascades all wet? Differentiation of donor-control in speciose systems. Ecology 73: $747-754$

Turner JT, Tester PA (1992) Zooplankton feeding ecologybacterivory by metazoan microzooplankton. J Exp Mar

Editorial responsibility: John Dolan, Villefrance-sur-Mer, France
Biol Ecol 160:149-167

Turner JT, Levinsen H, Nielsen TG, Hansen BW (2001) Zooplankton feeding ecology: grazing on phytoplankton and predation on protozoans by copepod and barnacle nauplii in Disko Bay, West Greenland. Mar Ecol Prog Ser 221: 209-219

Vadstein O, Harkjerr BO, Jensen A, Olsen Y, Reinertsen H (1989) Cycling of organic carbon in the photic zone of a eutrophic lake with special reference to the heterotrophic bacteria. Limnol Oceanogr 34:840-855

Verity PG, Smetacek V (1996) Organism life cycles, predation, and the structure of marine pelagic ecosystems. Mar Ecol Prog Ser 130:277-293

Wright SW, Jeffery SW, Mantoura RFC, Llewellyn CA, Bojrnland T, Repeta D, Welschmeyer N (1991) Improved HPLC method for the analysis of chlorophylls and carotenoids from marine phytoplankton. Mar Ecol Prog Ser 77: 183-196

Submitted: November 19, 2002; Accepted: June 5, 2003

Proofs received from author(s): September 8, 2003 